\title{
Fluoride compounds and their biological effects in aluminum potroom
}

\author{
${ }^{*}$ S. J. Shahtaheri, ${ }^{2}$ H. Assilian and ${ }^{3}$ R. Karimi-Kia \\ ${ }^{l}$ Department of Occupational Health, Tehran University of Medical Sciences, Tehran, Iran \\ ${ }^{2}$ Department of Occupational Health, University of Tarbiat Modarres, Tehran, Iran
}

\begin{abstract}
Respiratory system disorders occur in aluminum potroom workers despite pre-employment medical examinations. The aims of this study were to measure fluoride and its compounds in the potroom workplace atmosphere as well as workers' breathing zone air, examine the blood eozinophile cells count in the workers exposed to the fluoride compounds, and evaluate the respiratory symptoms and dysfunctions caused during the occupational exposure in potroom workers. To achieve these objectives, a study was carried out in 10 workplaces (potrooms) of Aluminum Producing Plants in Arak city located at Central Iran. Through this study, the data obtained from 160 workers (100 cases and 60 controls) were statically processed. The selected controls were matched for age, year of starting employment, smoking habit, and body mass index (BMI). The total fluoride compounds concentration of potroom, mean concentration of workers' breathing zone air at different job positions were measured showed high concentration compared to the Threshold Limit Value-Time Weighted Average (TLV-TWA). The incidence of respiratory symptoms, the number of blood eozinophile, and WBC counts were higher than normal range in case group. During this study, the susceptible aluminum potroom workers to occupational asthma were also identified. Through this study, it was concluded that, workers employing in the potroom in aluminum industries are at risk for respiratory disorders and a continuous workplace monitoring is needed to evaluate workers exposures.
\end{abstract}

Key words: Biological monitoring, fluoride compounds, potroom, occupational asthma

*Corresonding Author, Email: sjtaheri@sphtums.com

\section{Introduction}

From the viewpoint of occupational and environmental pollutants, potroom is one of the most important workplace in the aluminum manufacturing plants. During the reduction process, melted aluminum is produced by electrolysis of alumina $\left(\mathrm{Al}_{2} \mathrm{O}_{3}\right)$ in the electrolytic cells namely pots (Soyseth, et al., 1992 and 1994). $\mathrm{Al}_{2} \mathrm{O}_{3}$, the main component of bauxite ore (40-60\%), is dissolved in cryolite $\left(\mathrm{Na}_{3} \mathrm{AlF}_{6}\right)$ followed by electrically analysed (Benke, et al., 1998). In order to improve the analytical process, some fluoride compounds are also added to the pots content. Therefore, aluminum factory workers, depending on the type of process, are highly exposed to fluoride compounds. Also, aluminum potroom emissions can be considered as a common occupational asthma agent (Venables and Chan-Yeung, 1997). Fluoride compounds enter the body via inhalation, skin, and also gastrointestinal tracts (Desjardins, et al., 1994 and Sorgdrager, et al., 2001), causing different adverse effects, i.e. respiratory dysfunction
(Crebelli, et al. 2002, Rifat, et al. 1990 and White, et al., 1992), neurologic, cardiovascular, metabolic, digestive, and skeletal disorders (Radon, et al.,1999 and Thomas and Donnell, 1995) in which, the respiratory dysfunctions were evaluated through this study. To perform this investigation, fluorine compounds and their effects on blood cells and pulmonary functions as well as monitoring of workplace and workers' breathing zone air were considered to be studied.

\section{Materials and Methods}

The study was conducted at Arak Aluminum Manufacturing Plant located in Central Iran in 2001. There are ten large potrooms named WP1- WP10 in the tables and graphs, including 70 pots in each (totally 700 pots), serially located in the plant. Each pot is electrically charged through cathode and anode electrodes where melted alumina is reduced to aluminum under a high current (60-68 kA with 
potential difference of $5 \mathrm{v})$. Employees working at potrooms were mostly complaining against respiratory disorders such as bronchial hyper responsiveness (BHR) and work-related asthma symptoms during their course of employment, in which, the common symptoms are a combination of chest tightness and wheezing improving on days of away from work. This study was constructed to investigate the environmental fluoride compounds released in the potroom workplaces during electrolytic reduction of the alumina to produce aluminum as well as their effectiveness on the workers' biological system. Through this investigation, 100 workers as case group (occupationally exposed) and 60 official personnels who were all healthy adults considered as control group (without occupational exposure to the compounds of interest) were taken into account for exposure monitoring. Both groups, regarding to the age, height, employment history, smoking habit and body mass index

(BMI) were matched. In order to achieve the objectives of the study, the methods performed were as follow:

All individuals were requested to fill out a questionnaire to collect information about their personal characters, job history, type of current job, smoking habit, respiratory symptoms, and skin sensitization. Individuals smoking more than five cigarettes a day were considered as smokers. Fluoride compounds were sampled from the workplace atmosphere and workers' breathing zone air followed by their analysis. In order to measure the fluoride compounds, the ASTM method, no. D4765-88, was used (ASTM, 1994). Through this method, dusts and gaseous samples were measured simultaneously. To perform this stage, particulates were collected by membrane filters and gases were adsorbed by means of alkaline cellulose pads. The filters were then burned and dissolved in a buffer solution. The cellulose pads also were dissolved in the buffer solution followed by analysis, using an ionselective electrode system. To study the effects of the pollutant of interest on pulmonary functions and subsequent symptoms, different lung volumes were measured before and after working shifts, including case and control groups. The test was included measurement of vital capacity (VC), forced vital capacity (FVC), forced expiratory volume in one second $\left(\mathrm{FEV}_{1}\right), \mathrm{FEV}_{1} / \mathrm{FVC}$, forced midexpiratory flow (FMEF or $\mathrm{FEF}_{25-75}$ ), and peak expiratory flow (PEF). Blood samples were also taken followed by counting WBC, neutrophyl, lymphocyte, eosinophil, monocyte, and hematocrit in both case and control groups.

To compute the contribution of each potential risk factor, in statistical tests, a 95\% confidence interval was used as the limit of significance. Statistical analyses were performed on a personal computer with the Statistical Package for Social Sciences (SPSS/PC version 9.05).

\section{Results}

The characteristic of study groups have been shown in Table 1. Results obtained from measurement of the potroom workplace air have been illustrated in Table 2 .

Table 1: Characteristics of the subjects of study groups

\begin{tabular}{|c|c|c|c|}
\hline $\begin{array}{c}\text { Study } \\
\text { group } \\
\text { Individual } \\
\text { variables }\end{array}$ & $\begin{array}{l}\text { Case } \\
\text { group } \\
\mathrm{M} \pm \mathrm{SD}, \\
\mathrm{N}=100 \\
\end{array}$ & $\begin{array}{l}\begin{array}{l}\text { Control } \\
\text { group }\end{array} \\
\mathrm{M} \pm \mathrm{SD}, \\
\underline{\mathrm{N}=100} \\
\end{array}$ & P-value \\
\hline Height (cm.) & $172.9 \pm 5.97$ & $174.2 \pm 5.50$ & 0.169 \\
\hline Age (year) & $32.6 \pm 5.52$ & $32.8 \pm 6.42$ & 0.868 \\
\hline $\begin{array}{c}\text { Work history } \\
\text { (year) }\end{array}$ & $8.42 \pm 3.22$ & $7.98 \pm 5.17$ & 0.511 \\
\hline
\end{tabular}

Table 2: Total concentration of fluoride compounds in different workplaces of aluminum potroom $\left(\mathrm{mg} / \mathrm{m}^{3}\right)$

\begin{tabular}{|cccc|}
\hline $\begin{array}{c}\text { Sampling } \\
\text { site }\end{array}$ & $\begin{array}{c}\text { Particle } \\
\text { Mean } \pm \text { SD, } \\
\text { N=5 }\end{array}$ & $\begin{array}{c}\text { Gean } \pm \text { SD, } \\
\text { M=5 }\end{array}$ & $\begin{array}{c}\text { Total conc. } \\
\text { of fluoride } \\
\text { compounds } \\
\left(\mathrm{mg} / \mathrm{m}^{3}\right)\end{array}$ \\
\hline WP1 & $0.91 \pm 0.22$ & $0.32 \pm 0.20$ & 1.20 \\
\hline WP2 & $1.59 \pm 0.51$ & $0.92 \pm 0.07$ & 1.95 \\
\hline WP3 & $1.12 \pm 0.26$ & $1.25 \pm 0.21$ & 2.30 \\
\hline WP4 & $1.72 \pm 0.41$ & $1.24 \pm 0.49$ & 2.96 \\
\hline WP5 & $1.33 \pm 0.23$ & $1.88 \pm 0.25$ & 3.21 \\
\hline WP6 & $1.31 \pm 0.26$ & $0.56 \pm 0.20$ & 1.86 \\
\hline WP7 & $0.56 \pm 0.22$ & $0.98 \pm 0.16$ & 1.54 \\
\hline WP8 & $1.08 \pm 0.38$ & $0.92 \pm 0.25$ & 2.01 \\
\hline WP9 & $1.06 \pm 0.56$ & $0.86 \pm 0.22$ & 1.92 \\
\hline WP10 & $0.81 \pm 0.05$ & $0.55 \pm 0.14$ & 1.33 \\
\hline
\end{tabular}

WP: Workplace

Threshold Limit Value-Time Weighted Average

$($ TLV-TWA $)=2.5 \mathrm{mg} / \mathrm{m}^{3}$ 
As it can be seen, workplaces No. 4 and 5 showed total fluoride concentrations more than TLV-TWA recommended by ACGIH (ACGIH, 2002), $\left(2.96 \mathrm{mg} / \mathrm{m}^{3}\right.$ and $3.21 \mathrm{mg} / \mathrm{m}^{3}$ respectively). However, there was no significant difference between total fluoride concentrations in the various potroom. Workplaces No. 1 and 10 showed the minimum total concentration of fluoride compounds $\left(1.2 \mathrm{mg} / \mathrm{m}^{3}\right.$ and $1.33 \mathrm{mg} / \mathrm{m}^{3}$ respectively). As the Table 1 shows, the level of particles and gases amounts in these workplaces were also relatively low. The results showed that, there was a significant difference between gaseous fluoride compounds in workplaces No. 1 and 5 $(\mathrm{p}<0.001)$, workplaces No. 5 and $6(\mathrm{p}=0.002)$, and workplaces No. 5 and $10(\mathrm{p}=0.011)$, also, between particle fluoride compound in workplaces No. 1 and 4 ( $<<0.001)$, workplaces No. 4 and $7(\mathrm{p}<0.001)$. Figure 1 illustrate the total concentrations of fluoride compound in the workers' breathing zone. As the results show, all amounts are significantly more than the TLV-TWA except supervisors' breathing zone. According to the obtained results, there was no significant difference between various occupations $(\mathrm{p}=0.085)$. The results gained from evaluation of the workers' respiratory symptoms have been showed in Figure 2, showing significant differences between the case and control groups for all respiratory symptoms $(\mathrm{p}<0.001)$. Tables 3 and 4 shows the spirometric parameters measured in both case and control groups at before and after working shifts.
The data illustrated significant differences between case and control groups except $\mathrm{FEV}_{1} / \mathrm{FVC}$ (the initial symptoms of appearing occupational asthma). Finally, the hematology indexes, measured in exposed employees' blood, can be seen in Table 5, in which, WBC, eosinophil, and WBCx \% E counts showed significant differences in the case and control groups $(\mathrm{p}<0.001, \mathrm{p}<0.001$, and $\mathrm{p}=0.004$ respectively).

\section{Discussion and Conclusion}

The total fluoride componds concentration of workplaces 4 and 5 were more than TLVTWA i.e. $2.5 \mathrm{mg} / \mathrm{m}^{3}$ recommended by ACGIH, 2002 (Threshold, 2002). Therefore, the emission sources of the pollutants should be of the most special attentions and needed to be highly controlled by means of using more powerful ventilation systems either generally or locally as well as a continuous environmental and biological monitoring of the emitted compounds. It also seems that, the location of the workplaces can play an effective role in producing the high concentration of pollutants as the workplaces No. 4 and 5 have been located in the middle, whereas, the workplaces No 1 and 10 have been located at the two sides of the end and the beginning of the potroom plant. The mean concentrations of the workers' respiratory zone air at different job positions were more than TLV-TWA except supervisors.

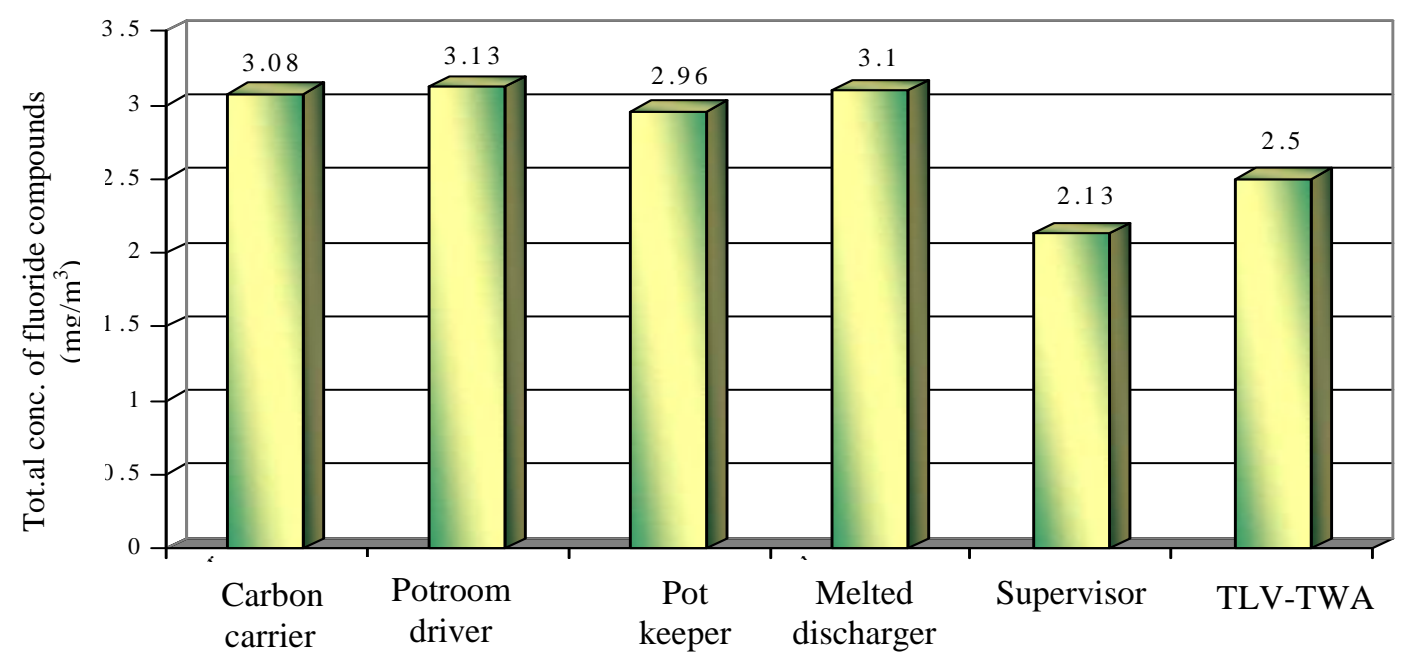

"Occupation"

Figure 1: Total concentration of fluoride compounds in respiratory zone air of potroom workers 


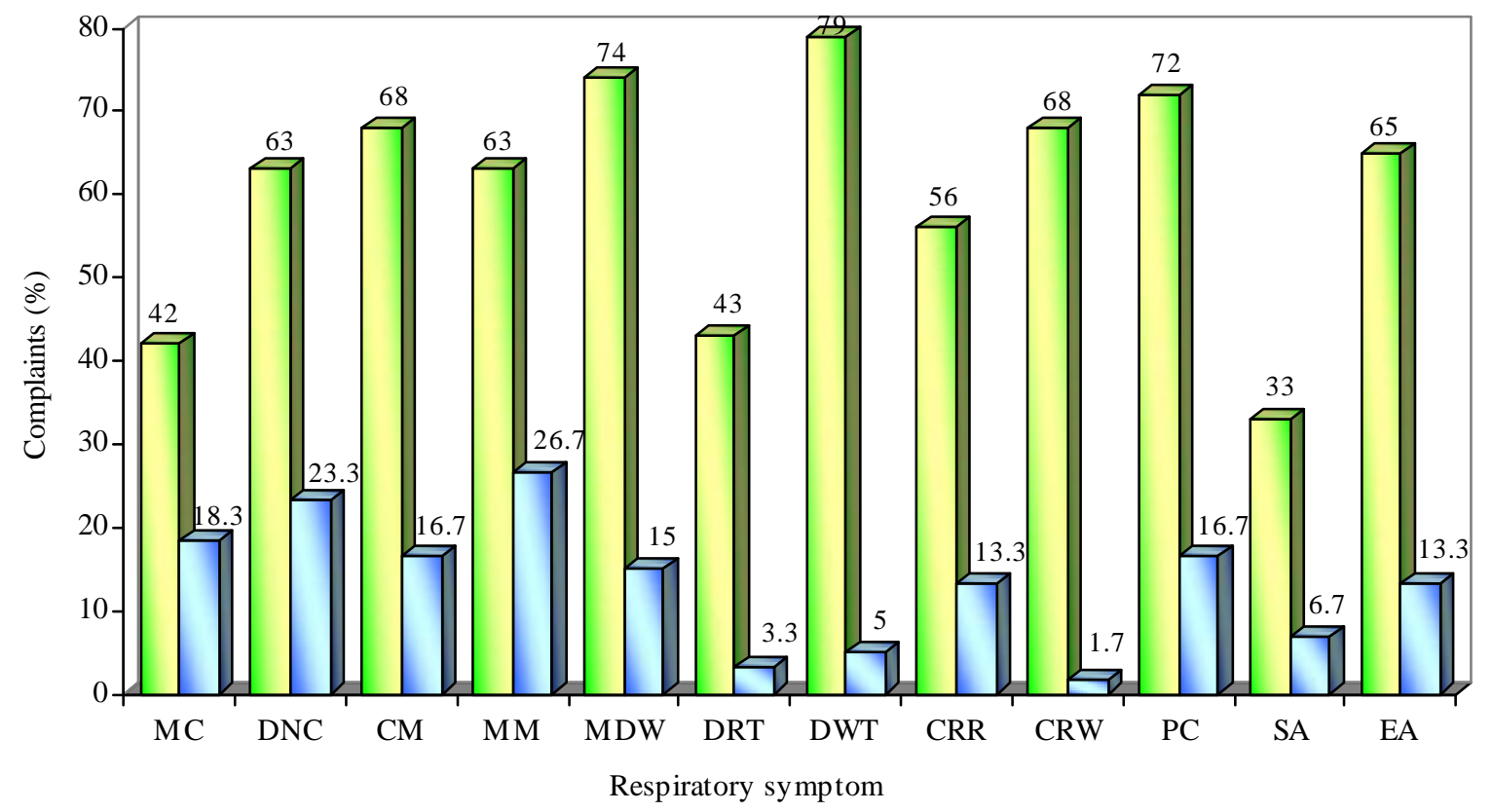

MC: Morning cough DNC:Day-night cough

$\square$ Case $\square$ Control

DWT: Dyspnea at working time

CM: Cough with mucus

CRR: Chest rale at rest

MM: Morning mucus

CRW: Chest rale at work

MDW: Mucus during work

PC: Pressure in chest

DRT: Dyspnea at resting time

SA: Skin allergy

EA: Eye allergy

Figure 2: Significant differences between the case and control groups for all respiratory symptoms $(\mathrm{p}<0.001)$

Table 3: Spirometric parameters for case group before and after working shift

\begin{tabular}{|cccc|}
\hline $\begin{array}{c}\text { Shift type spirometric } \\
\text { parameter }\end{array}$ & $\begin{array}{c}\text { Before working shift } \\
\mathrm{M} \pm \mathrm{SD}, \mathrm{N}=100\end{array}$ & $\begin{array}{c}\text { After working shift } \\
\mathrm{M} \pm \mathrm{SD}, \mathrm{N}=100\end{array}$ & P-value \\
\hline $\mathrm{VC}(\%)$ & $99.11 \pm 17.33$ & $95.87 \pm 16.33$ & 0.000 \\
\hline FVC(\%) & $100.05 \pm 18.44$ & $96.70 \pm 19.95$ & 0.027 \\
\hline FEV1(\%) & $109.86 \pm 22.63$ & $99.06 \pm 21.64$ & 0.000 \\
\hline FEV1/FVC(\%) & $2.00 \pm 3.28$ & $1.5 \pm 3.0$ & 0.000 \\
\hline FEF25-75 & $99.39 \pm 33.07$ & $83.34 \pm 32.38$ & 0.000 \\
\hline FEF(\%) & $93.99 \pm 24.35$ & 85.4326 .33 & 0.000 \\
\hline
\end{tabular}

Table 4: Spirometric parameters for control group before and after working shift

\begin{tabular}{|cccc|}
\hline $\begin{array}{c}\text { Shift type spirometric } \\
\text { parameter }\end{array}$ & $\begin{array}{c}\text { Before working shift } \\
\text { Mean } \pm \text { SD, N=60 }\end{array}$ & $\begin{array}{c}\text { After working shift } \\
\text { Mean } \pm \text { SD, N=60 }\end{array}$ & P-value \\
\hline VC $(\%)$ & $106.4 \pm 11.9$ & $105.4 \pm 11.9$ & 0.940 \\
\hline FVC(\%) & $108.1 \pm 11.9$ & $107.5 \pm 12.1$ & 0.014 \\
\hline FEV1(\%) & $117.3 \pm 14.65$ & $116.2 \pm 14.1$ & 0.055 \\
\hline FEV1/FVC(\%) & $3.86 \pm 5.3$ & $3.70 \pm 5.55$ & 0.017 \\
\hline FEF25-75 & $100.3 \pm 29.2$ & $97.7 \pm 23.9$ & 0.247 \\
\hline FEF(\%) & $113.2 \pm 24.2$ & $109.4 \pm 22.8$ & 0.247 \\
\hline
\end{tabular}


Table 5: The hematology parameters (blood cells) measured in case and control groups

\begin{tabular}{|cccc|}
\hline $\begin{array}{c}\text { Hematology parameters } \\
\text { (blood cells) }\end{array}$ & $\begin{array}{c}\text { Case group } \\
\text { mean } \pm \mathrm{SD}, \mathrm{N}=100\end{array}$ & $\begin{array}{c}\text { Control groups } \\
\text { mean } \pm \mathrm{SD}, \mathrm{N}=60\end{array}$ & P-value \\
\hline WBC (count/ml) & $6248.8 \pm 1090.2$ & $6866.6 \pm 1226.0$ & 0.001 \\
\hline Neutrophil & $53.0 \pm 9.1$ & $55.3 \pm 10.4$ & 0.145 \\
\hline Lymphocyte & $40.8 \pm 9.4$ & $40.6 \pm 9.6$ & 0.892 \\
\hline Eosinophil. & $4.8 \pm 4.3$ & $2.7 \pm 2.6$ & 0.001 \\
\hline WBC $\% \mathrm{E}$ & $301.3 \pm 267.7$ & $188.8 \pm 177.2$ & 0.004 \\
\hline Moncyte & $1.5 \pm 0.7$ & $1.3 \pm 0.7$ & 0.106 \\
\hline Hematocrit & $47.0 \pm 3.2$ & $47.4 \pm 2.8$ & 0.542 \\
\hline
\end{tabular}

According to the type of supervisors responsibilities, they usually go through workplaces (a walk through job) temporarily, in which, most probably, their type of employments could be a major reason for having a low exposure to the fluoride compounds. The TLV-ceiling for HF is $3 \mathrm{ppm}$, so, workers like carbon carriers, potroom drivers, and melted dischargers should be more protected as they are at risk of over-exposed positions to the fluoride compounds. In this case, the workers should use carefully their highly efficient personal protective devices especially put on their face masks, having suitable filter pore size especially when they are near and at the aluminum production procss. Some attempts such as minimizing the exposure time and changing hazordous jobs periodiclly among the workers, can be effective alternative choices. The incidence of respiratory symptoms in case group was significantly higher than control group. The low lung function levels in the workers exposed to the fluoride compounds can be considered as a distinct symptom of showing primary alarm in causing occupational asthma (potroom asthma). Performing the pre and post-employment and also periodic especial clinical tests can help to monitor and find workers who are at risk followed by applying suitable treatments. According to the obtained results, bloodparameters i.e. eosinophil and WBC have been increased in exposed workers, showing a significant relation in causing respiratory dysfunctions as well as occupational asthma. Therefore, eozinophile count in the blood of susceptible workers to asthma is a vital and key test for protecting them against occupational disease in aluminum potroom. It is worth considering that, potroom workers even in industrialized countries and perhaps in modern aluminum manufactures could be at risk for chronic and acute respiratory dysfunctions. Therefore, a continuous environmental and biological monitoring is needed to eliminate or decrease the pollutants released in aluminum industries and subsequent promotion of the workers' safety and health at work. It is also believed that, further studies are necessary, concentrating on restrictive lung function parameters such as diffusing capacity and residual volume in aluminum potroom workers. Finally, a systematic and facilitated educations i.e. notifying accordingly the employees of "how to do the job right" and "how to protect themselves against pollutants" can play the main roles in producing a safe, healthful, and even economic industrialized world.

\section{Acknowledgments}

This programe of the work has received valuable assistance from University of Tarbiat Modarres, Tehran, Iran to support Mr. KarimiKia. Hereby, sincere cooperations are highly appreciated. The authors also thank the Aluminum Manufacturing Plant management for all their helps in the field experiments and administrations.

\section{References}

American Society for Testing and Materials (ASTM) D4765-88 1994

Benke, G, M. Abramson, M. Sim, Exposures in the alumina and primary aluminum industry, an historical review. Ann Occup Hyg, 42: 173-189, 1998

Crebelli, R., P. Carta, C. Andreoli G. Aru, G. Dobrowolny, S. Rossi and A. Zijno, Biomonitoring of primary aluminum industry workers: detection of micronuclei and reparable DNA lesions by alkaline SCGE. Mutation Research, 516: 63 70, 2002 
Desjardins, A., J. Bergeron, H. Ghezzo, A. Cartier and J. Malo, Aluminum potroom asthma confirmed by monitoring of forced expiratory volume in one second. Am J Respir Ceit Care Med, 150: 1714-1717, 1994

Radon K., D. Nowak and R. Heinrich-Ramm, Respiratory health and fluoride exposure in different parts of the modern primary aluminum industry. Int. Arch. Occup. Environ. Health, 72 297-303 1999

Rifat, S. L., M. R. Eastwood, D. R. McLachlam and P. N. Corey, Effect of exposure of miners to aluminum powder. Lancet, 336: 1162-1165, 1990

Sorgdrager B., A. J. Loof , M. P. Teake, F. J. Dijk and J. G. Monchy, Factors affecting FEV in workers with potroom asthma after their removal from exposure. Int Arch Occup Environ Health, 74: 55582001

Soyseth, V., J. Kongerud, J. Boe and T. Fonneland, Bronchial responsiveness and work-related asthma in aluminum potroom workers: effect of 1992 removal from exposure. Eur Respir J, 5: 829833, Soyseth, V., J. Kongerud, J. Ekstrand and J. Boe, Relation between exposure to fluoride and bronchial responsiveness in aluminum potroom workers with work-related asthma-like symptoms. Thorax, 49: 984-989 1994

Thomas V. and O. Donnell, Asthma and respiratory problems, The Science of the Total Environment, 163: 137-145 1995

Threshold Limit Value for Chemical Substances in the Work Environment and physical agents and Biological Exposure Indices, ACGIH, 2002

Venables, M. K. and M. Chan-Yeung, Occupational asthma. Lancet, 349: 1465-146, 1997

White, D. M., W. T. Longstreth, L. Rosenstock, H. J. Keith, H. J. Claypool, C. A. Brodkin, B. D. Townes, Neurologic syndrome in 25 workers from an aluminum smelting plant. Arch Intern Med, 152: 1443-1448 1992 